\title{
The Effectiveness of Content-Based Language Teaching and Task-Based Language Teaching in Teaching Reading to Learners of Military English
}

\author{
Yanxia Li ${ }^{1,}$, , Zhuo Chen ${ }^{2}$ \\ ${ }^{1}$ Department of Fundamental Courses Teaching, PLA Strategic Support Force Information Engineering University, Zhengzhou, China \\ ${ }^{2}$ School of Foreign Studies, South China Normal University, Guangzhou, China
}

Email address:

617439132@qq.com (Yanxia Li),282861491@qq.com (Zhuo Chen)

${ }^{*}$ Corresponding author

To cite this article:

Yanxia Li, Zhuo Chen. The Effectiveness of Content-Based Language Teaching and Task-Based Language Teaching in Teaching Reading to Learners of Military English. English Language, Literature \& Culture. Vol. 4, No. 2, 2019, pp. 39-43. doi: 10.11648/j.ellc.20190402.12

Received: April 22, 2019; Accepted: June 2, 2019; Published: June 24, 2019

\begin{abstract}
This study explored the effectiveness of Task-Based Language Teaching (TBLT) and Content-Based Language Teaching (CBLT) on the reading ability of military English learners. 120 sophomore learners of military English were pretested and then homogenized and evenly assigned to four classes, with two belonging to the control group and the other two the experimental group. The control group received reading instruction based on CBLT, while the experimental group received reading instruction based on TBLT, both two sessions a week for 10 weeks. After the intervention, they were posttested. Then, their pretest scores and posttest scores were analyzed on SPSS 19.0 using paired samples t-test and independent samples t-test. A follow-up interview was also carried out to collect students' feedback on the teaching method used. The results show that both the TBLT group and the CBLT group improved significantly regarding their reading ability from the pretest to the posttest, with the TBLT group outperformed the CBLT group in the posttest. It can be concluded that both TBLT and CBLT methods are effective in teaching reading comprehension to learners of military English, with TBLT method being more effective. A follow-up interview was carried out to explore the underlying reasons and some pedagogical implications are listed accordingly.
\end{abstract}

Keywords: English for Specific Purposes, Content-Based Language Teaching, Task-Based Language Teaching, Reading Comprehension

\section{Introduction}

Due to the popularization of English and the increase of international communication, the importance of English for Specific Purposes (ESP) is gaining more and more recognition in colleges in China. ESP courses, as they put together both "the acquisition of specific information and the development of language skills" [1:4181], have been taught to students of various majors, such as business, engineering, medicine, information technology, law, etc. Consequently, it is urgent and beneficial to pin down language teaching methods that are effective for different language skills in ESP classes.

Content-Based Language Teaching (CBLT) and Task-Based Language Teaching (TBLT) are two of the most frequently researched, experimentally proven effective, thus most advocated methods in English as a Foreign Language
(EFL) classes. However, their particular effectiveness in ESP classes has been sparsely studied and thus remained to be analyzed. This paper aims to explore the effectiveness of CBLT and TBLT in teaching reading to learners of military English in ESL classes and tries to find out their relative effectiveness. More specifically, the present study aims to answer the following three research questions:

1. Is Content-Based Language Teaching effective in teaching reading to learners of military English?

2. Is Task-Based Language Teaching effective in teaching reading to learners of military English?

3. Is there any significant difference between CBLT and TBLT in their effectiveness in teaching reading to learners of military English? 


\section{Theoretical Background}

\subsection{ESP}

The history of ESP can be dated back to the 1960s [2: 149]. Ever since then, it has been variously defined and enormously studied [3: 300]. No matter how it is defined, it is generally agreed by ESP researchers that it possesses the following key features. a. It is designed to meet specific learner needs. b. It makes use of the underlying methodology and activities of the disciplines and professions it serves. c. It depends on the language (grammar, lexis, register, etc.), skills, discourse and genre relevant to these activities. $d$. It may be related to or specifically designed for specific scientific fields. e. It may use a different methodology than that of general English [4: 4-5]. As English is becoming more and more popular in the world and college students' English proficiency is becoming higher and higher, general English teaching has long been found inadequate in meeting students' needs for more major-specific language competence. Instead, ESP has become one of the most prominent areas of EFL today. English for business, medicine, economics and many more are among its various sub-branches.

\section{2. $C B L T$}

CBLT is a significant approach in language education [5]. It is an approach which integrates language and content in instruction [6]. It falls under the more general rubric of communicative language teaching (CLT), thus it is learner rather than teacher centered [7]. In such classrooms, students learn through doing and are actively engaged in the learning process. According to Wikipedia [8], the integration of language and content teaching is perceived by the European Commission as "an excellent way of making progress in a foreign language". CBLT effectively increases learners' English language proficiency as well as teaches them the skills necessary for the success in their specific professions. Thus, it is assumed to be an effective method in teaching ESP which also focuses on content-specific English knowledge.

\section{3. $T B L T$}

As another development of CLT, TBLT focuses on asking students to do meaningful tasks using the target language, such as asking the way, making a phone call, attending an interview and other information gap tasks. Tasks are the basic and core units in TBLT [9]. Tasks should be designed based on reliable criteria [10]. According to Rod Ellis [11: 17-18], a task has four main characteristics. a. A task involves a primary focus on (pragmatic) meaning. b. A task has some kind of 'gap' (information gap, reasoning gap, and opinion gap). c. The participants choose the linguistic resources needed to complete the task. d. A task has a clearly defined, non-linguistic outcome. These cognitively engaging tasks can involve students directly with the language being taught and reflect authentic and purposeful use of language, thus resulting in language-learning experiences that are pleasurable and effective. It has proven to be highly effective in language teaching [12]. For teaching ESP, which focuses on the particular use of specialized English knowledge, TBLT is also supposed to be proper.

In all, it is reasonable to choose CBLT and TBLT as the teaching methods to be researched. It's duly followed that their relative effectiveness should be made clear.

\section{Methodology}

\subsection{Participants}

The students in the subject university are required to take college English courses in the first two years of their college life and take additional military English course in the second term of the second academic year. The participants of the study were 120 sophomore students randomly chosen from the students across all majors in the same grade. They were pretested before the study and based on their pretest scores they were homogenized and evenly assigned to four classes, with two belonging to the control group and the other two the experimental group.

\subsection{Instruments}

The pretest and posttest were both composed of 4 reading passages about military affairs, with 40 items and a total score of 50 points. In order to achieve high validity and reliability, the reading tasks were pilot-studied. The Parallel-Forms Reliability between the two test papers was 0.778 , which is adequate enough. The reading course book used in the experimental intervention was A Reading Course in Military English 2 published by National Defense Industry Press in 2010. This book covers a wide range of military English reading texts, such as military figures, notable campaigns, hi-tech $\&$ information war and future war, etc., which had been used for two years in the subject university and been proved to be suitable for teaching reading to learners of military English.

\subsection{Procedure}

The study was carried out during the first ten weeks of the participants' second term in the second academic year. After the pretest, the 120 participants were assigned to 4 classes, with each containing 30 students. Two (Class 1 and 2) were used as the control group and the other two (Class 3 and 4) the experimental group. The reason why the experimental group and the control group each contained two classes is to obtain large sample size and at the same time to obtain proper class size, because larger sample size can generate more reliable results and a class of 30 students is generally regarded as proper for teaching English reading comprehension. The four classes all received reading instruction for 2 sessions (45minites a session) a week for 10 weeks.

The difference lies in that the control group (Classes 1 and 2) received reading comprehension instruction based on CBLT, while the experimental group (Classes 3 and 4) on TBLT. In the control group, the reading texts on military affairs, for example, US military forces, the United Nations peacekeeping 
forces, US military academy at West Point, etc., were taught under the principles of CBLT. The students read the texts and did related exercise. The researcher and teacher used pictures, audio clips, videos, PPT, etc. as much as possible, to motivate student's interest in the subject matter and facilitate students to engage in meaningful communication about the topics in English. Therefore, a majority of class time is spent in pair works and group discussions of the military matters and the issues that arise naturally from them. The classroom activities used include: brief quizzes; student brainstorming of some questions for group discussion; presentations made by the students to share information, and whole-group viewing key scenes for group discussion and analysis. The syllabuses were developed according to the principles elaborated in [13: 10-13].

In the experimental group, the same reading texts were taught, but abiding by the principles of TBLT. More specifically, the students had to finish specially designed reading tasks, such as draw an information table after reading the text, perform a group discussion, carry out a class survey and write a survey report, etc. All of the tasks and the syllabuses were designed according to Ellis' 8 principles for designing lessons using task-based methodology [14: 97-98].

After the experimental intervention, the students were posttested. Then, their pretest score and posttest score were analyzed on SPSS 19.0 using independent samples t-test and paired samples t-test. A follow-up interview was also carried out to collect students' feedback on the teaching method used.

\section{Results and Discussion}

\subsection{Pretest Results for the Two Groups}

The descriptive statistics for the performance of each of the two groups on the pretest are given in the following table.

Table 1. Paired Samples Statistics on the Pretest.

\begin{tabular}{llllll}
\hline Group & Method & $\begin{array}{l}\text { Std. } \\
\text { Deviation }\end{array}$ & $\begin{array}{l}\text { Std. Error } \\
\text { Mean }\end{array}$ & Mean & N \\
\hline Control & CBLT & 3.90 & 1.42 & 25.67 & 60 \\
Experimental & TBLT & 4.16 & 1.50 & 26.11 & 60 \\
\hline
\end{tabular}

In order to see if there is any significant difference between the two groups at the outset, an independent samples T-test was used. The results of T-test are presented in Table 2 below.

Table 2. Independent Samples t-test for the pretest score of the control group and the experimental group.

\begin{tabular}{llll}
\hline Control group & \multicolumn{1}{l}{ Experimental group } & \\
\hline Pretest Mean & & $\boldsymbol{t}$ & Sig. \\
\hline 25.67 & 26.11 & .675 & .522 \\
\hline
\end{tabular}

It is clear from Table 2 that the observed t-value is.675, but the $p$ value is.522, which means that there wasn't any significant difference between the performances of the two groups at the beginning of the study and the two groups indeed belonged to the same population when the study started.

\subsection{Pretest and Posttest Results for the CBLT and TBLT Groups}

In order to find out if teaching reading through each of the two methodologies had any significant effect on the reading ability of the learners, the learners' scores on both pretest and posttest were compared for each group by using matched samples t-tests.

\subsubsection{Pretest and Posttest Results for the CBLT Group}

The descriptive statistics for the performances of the control group is given in Table 3. The mean score for the pretest is 25.67 with a standard deviation of 3.90 , while the mean score for the posttest with a standard deviation of 5.42 is 34.32 . An observed difference can be seen between the performances in the posttest and pretest. Nevertheless, the question is whether such a difference is statistically significant or not.

Table 3. Paired Samples Statistics for CBLT pretest and posttest results.

\begin{tabular}{lllll}
\hline Control Group & Mean & Std. Deviation & Std. Error Mean & N \\
\hline Pretest & 25.67 & 3.90 & 1.42 & 60 \\
Posttest & 34.32 & 5.42 & 1.98 & 60 \\
\hline
\end{tabular}

Accordingly, matched samples T-test was used to check the significance of such a difference. The results are presented in Table 4. The obtained T-value is 9.02 (sig..004, $\mathrm{p}<.05$ ). Consequently, it can be concluded that content-based language teaching has been effective in teaching reading comprehension to ESP learners and the students' reading ability has improved significantly.

Table 4. Paired Samples t-test for CBLT group.

\begin{tabular}{llll}
\hline Pretest & Posttest & $t$ & Sig. \\
\hline 25.67 & 34.32 & $9.02 *$ & .003 \\
\hline$* \mathrm{P}<.05$ & & &
\end{tabular}

So, the first research question is duly answered and Content-Based Language Teaching is effective in teaching reading to learners of military English.

\subsubsection{Pretest and Posttest Results for the TBLT Group}

The descriptive statistics for the performances of the task-based group is given in Table 5. The mean score for the pretest is 26.11 with a standard deviation of 4.16 , but the mean score for the posttest is 38.81 with a standard deviation of 4.19 . Therefore, an observed difference between the performances of the task-based group from the posttest to the pretest can be seen.

Table 5. Paired Samples Statistics for TBLT pretest and posttest results.

\begin{tabular}{lllll}
\hline $\begin{array}{l}\text { Experimental } \\
\text { Group }\end{array}$ & Mean & Std. Deviation & $\begin{array}{l}\text { Std. Error } \\
\text { Mean }\end{array}$ & N \\
\hline Pretest & 26.11 & 4.16 & 1.50 & 60 \\
Posttest & 38.81 & 4.19 & 1.63 & 60 \\
\hline
\end{tabular}

As shown in Table 6, the obtained t-value at $\mathrm{p}<.05$ is 8.73 . Therefore, the difference between the performances of the TBLT Group on the posttest and on the pretest is statistically significant. This shows that the task-based group's reading comprehension ability has improved significantly after the 
experiment intervention.

Table 6. Paired Samples t-test for the TBLT group.

\begin{tabular}{llll}
\hline Pretest & Posttest & $\boldsymbol{t}$ & Sig. \\
\hline 26.11 & 38.81 & $8.73 *$ & .001 \\
\hline
\end{tabular}

$* \mathrm{P}<.05$

Consequently, the second research question can also be answered and Task-Based Language Teaching is effective in teaching reading to learners of military English.

\subsection{Posttest Results for the CBLT and TBLT Groups}

Since the reading ability of both of the CBLT and TBLT groups has been improved, the remaining and main question of the current study is to check if there is any significant difference between CBLT and TBLT in their effectiveness in teaching reading to learners of military English. The descriptive statistics for the performances of the two groups on the posttest are shown in Table 7.

Table 7. Paired Samples Statistics on the Posttest.

\begin{tabular}{llllll}
\hline Group & Method & $\begin{array}{l}\text { Std. } \\
\text { Deviation }\end{array}$ & $\begin{array}{l}\text { Std. Error } \\
\text { Mean }\end{array}$ & Mean & N \\
\hline Control & CBLT & 5.42 & 1.98 & 34.32 & 60 \\
Experimental & TBLT & 4.19 & 1.63 & 38.81 & 60 \\
\hline
\end{tabular}

As shown in Table 7, the mean score for the TBLT Group on the posttest is 38.81 and the mean score for the CBLT group is 34.32. Therefore, there is an observed difference between the performances of the two groups on the posttest. However, in order to check if such a difference is statistically significant or not, an independent samples t-test was used.

Table 8. Independent Samples T-test for the posttest score of the control group and the experimental group.

\begin{tabular}{llll}
\hline Control group & Experimental group & & \\
\hline Posttest Mean & & $\boldsymbol{t}$ & Sig. \\
\hline 34.32 & 38.81 & 3.52 & .002 \\
\hline
\end{tabular}

$* \mathrm{P}<.05$

As is clear from Table 8, the t-value for the posttest score of the control group and the experimental group is 3.52 (sig..002). Therefore, it can be concluded that there is significant difference between CBLT and TBLT in their effectiveness in teaching reading to learners of military English. More specifically, task-based language teaching is more effective than content-based language teaching in teaching reading to learners of military English.

\section{Conclusion}

As it was observed above, the teaching method that focuses on the language content and the one that centers on using language to finish meaningful tasks are both effective in teaching English for specific purposes. The reason is understandable, i.e. the two teaching methods and ESP are consistent in their underlying view of language: they treat language as a tool in performing meaningful and authentic tasks, not a subject in its own right [15]. In the follow-up interview, students generally gave positive feedback on two teaching methods used. In the CBLT class, the content, that is, the military matters, appeals to them. In the TBLT class, the meaningful tasks engage them.

As for the superiority of TBLT over CBLT in teaching ESP, the follow-up interview also shed some light. The students in the TBLT group generally reflected that when carrying out the assigned tasks, they had to recall and make use of all their previous related language knowledge and to master new knowledge to successfully finish the task. In this process, their attention was more concentrated and the reading skills were more fully practiced. Moreover, in CBLT the focus is on the content and the students are mostly concerned with mere information or the subject matter and less concerned about the language. Their previous military knowledge can help them in reading, even if they lack related language knowledge. In this case, the learning of language is compromised. Nevertheless, in TBLT, both the learning and the manipulation of language are considered. The tasks are at the service of the communication of meaning through language. What's more, the post-task phase of TBLT is nothing less than a languagefocus phase during which the teacher deductively teaches complicated formal aspects of language that proved problematic to the learners when performing the task [14: 95]. However, in CBLT, the focus on content renders a neglect of language. Therefore, for CBLT to be more effective, an extra conscious emphasis on language may do.

However, the present study is not without limitations. Among others, first, since military English reading is chosen as the teaching subject, the results cannot be readily and completely generalized to other ESP subjects or to other English skills. In addition, only CBLT and TBLT were chosen as the teaching method to be researched and other, maybe more effective methods are left out intentionally. Therefore, more empirical studies, on other ESP subjects and on other teaching methods, are needed.

\section{References}

[1] Popescu, A. (2012). Teaching ESP -1st year students of electronics and telecommunications. Procedia - Social and Behavioral Sciences 46: 4181-4185.

[2] Tzoannopouloua, M. (2015). Rethinking ESP: Integrating content and language in the university classroom. Procedia Social and Behavioral Sciences 173: 149-153.

[3] Swales, J. (1992). Language for specific purposes. In W. Bright (ed.), International Encyclopedia of Linguistics (Vol. 2). New York, Oxford: Oxford University Press. P. 300.

[4] Dudley-Evans, T., St John, M. (1998). Developments in English for Specific Purposes: A Multi-disciplinary Approac Brinton, Snow $h$. Cambridge: CUP.

[5] Brinton, D. M., Snow, M. A., \& Wesche, M. B. (1989). Content-based Second Language Instruction. New York: Newbury House. 
[6] Snow, M. A. (2016). Content-based language teaching and academic language development. Handbook of research in second language teaching and learning, 3, 159.

[7] Littlewood, W. (1981). Communicative Language Teaching: An Introduction. Cambridge: Cambridge University Press.

[8] Content-based instruction, (2015). Retrieved Jun. 5, 2015 https://en.wikipedia.org/wiki/Content-based_instruction.

[9] Ellis, R. (2000). Task-based Research and Language Pedagogy. Language teaching research. Oxford: Oxford University Press.

[10] Long, M. H. (2016). In defense of tasks and TBLT: Nonissues and real issues. Annual Review of Applied Linguistics, 36, 5-33.

[11] Ellis, R. (2003). Task-based Language Learning and Teaching. Oxford, New York: Oxford Applied Linguistics.
[12] Leaver, B. \& Willis, J. (2004). Task-Based Instruction in Foreign Language Education. Georgetown: Georgetown University Press.

[13] Kasper, Loretta F. (2000) Content-Based College ESL Instruction: Theoretical Foundations and Pedagogical Applications. In Loretta F. Kasper et al. (eds) Content-Based College ESL Instruction. New Jersey: Lawrence Erlbaum Associates. Pp. 3-25.

[14] Ellis, R. (2006). The Methodology of Task-Based Teaching. Journal of Foreign Language Education \& Research 4: 79-101.

[15] Faez, F., \& Tavakoli, P. (2018). Task-Based Language Teaching. ELT Development Series. TESOL Press. 